\title{
Identifikasi Bakteri Coliform pada Air Minum dalam Kemasan (AMDK) yang Diproduksi di Kota Batam
}

\section{Identification Of Coliform Bacteria on Bottled Mineral Water Produced in Batam City}

\author{
Fitrah Amelia
}

\author{
Prodi Pendidikan Matematika, FKIP, Universitas Riau Kepulauan, Batam-Indonesia \\ Koresponden: fitrahamelia@yahoo.com
}

\begin{abstract}
Abstrak
Tujuan penelitian ini adalah untuk mengetahui ada atau tidaknya bakteri coliform beserta jenisnya, yang terkandung dalam air minum dalam kemasan yang diproduksi di kota Batam. Populasi dari penelitian ini adalah seluruh air minum dalam kemasan diproduksi di kota Batam. Teknik pengambilan sampel menggunakan purposive sampling. Sampel diambil dari 8 merek air minum dalam kemasan yang diproduksi di kota Batam. Penelitian ini dilakukan di laboratorium Central Teknologi laboratorium medik, STIKES Perintis, Padang. Terhadap sampel dilakukan identifikasi Coliform yang dilakukan dengan metoda MPN (Most Probable Number). Pengujian MPN dilakukan dengan dua tahap yaitu, Uji Praduga (Presumptive Test) menggunakan medium LB (Lactosa Broth) dan Uji Konfirmasi (Confirmative Test) menggunakan medium BGLB (Brillian green laktosa broth). Dari hasil penelitian diperoleh hanya 2 sampel yang tidak mengandung bakteri coliform. Nilai MPN berkisar antara $2-\geq 979$ MPN/100 ml. Setelah dilakukan uji pelengkap dari 16 sampel yang dianalisa diperoleh 8 sampel mengandung bakteri diantaranya Klebsiella sp., Enterobacter, Pseudomonas sp., dan Salmonella sp.
\end{abstract}

Kata Kunci: Coliform, MPN, AMDK

\section{Abstract}

The purpose of this study was to determine the presence or absence of coliform bacteria and their types contained in bottled mineral water produced in Batam city. The population of this study is all bottled mineral water produced in Batam city. The sampling technique uses purposive sampling. Samples from 8 brands of bottled mineral water produced in Batam city. This research was carried out in the Central Technology laboratory of medical laboratories, STIKES Perintis, Padang. Coliform identification was carried out on the sample carried out by the MPN (Most Probable Number) method. MPN testing is carried out in two stages, namely, the Presumptive Test using the LB medium (Lactosa Broth) and the Confirmative Test using the BGLB medium (Brillian green lactose broth). From the results of the study it was found that only 2 samples that did not contain coliform bacteria. MPN value ranged from $2-\geq 979$ MPN/100 ml. After a complementary test of 16 samples analyzed 8 samples containing bacteria included Klebsiella sp., Enterobacter, Pseudomonas sp., and Salmonella sp.

Keysword: Coliform, MPN, AMDK

\section{PENDAHULUAN}

Sebagian besar dari tubuh manusia terdiri dari air dan manusia sebagai makhluk hidup tentu membutuhkan air untuk kelangsungan hidupnya. Oleh karena itu, kualitas air terutama untuk air minum harus mendapatkan perhatian utama. Air yang digunakan untuk air minum harus memenuhi berbagai persyaratan diantaranya secara fisik, air tidak berwarna, berasa dan berbau. Selain itu, air minum yang dikonsumsi harus higienis dan kandungan mikroba di dalamnya tidak melewati ambang batas yang diperbolehkan. Menurut Soemirat (2009), air 
minum yang ideal seharusnya jernih, tidak berwarna, tidak berasa, dan tidak berbau. Air minum seharusnya tidak mengandung kuman patogen dan segala mahluk yang membahayakan kesehatan manusia. Berdasarkan penelitian Hussain, et. al., (2011) air merupakan tempat bagi kolonisasinya berbagai jenis mikroba seperti bakteri, fungsi maupun yeast.

Penyakit yang penularannya terjadi melalui air yang terkontaminasi bakteri atau fungi patogen dan ditularkan kepada manusia melalui mulut atau sistem pencernaan disebut Waterborne disease. Penyakit paling umum yang disebabkan oleh Waterborne disease adalah diare yang disebabkan oleh adanya pencemaran bakteri jenis Coliform pada air. Diare merupakan salah satu penyebab kematian pada anak dibawah usia lima tahun atau sekitar 15\% tahun 2008 (Kusuma \& Rasyid, 2015; Winata \& Hartantyo, 2013). Pengujian air secara mikrobiologi sangat diperlukan untuk mengukur kualitas proses sanitasi dan derajat kontaminasi cemaran mikroba dalam air terutama untuk air yang digunakan sehari-hari. Salah satu air yang perlu diperhatikan kandungan mikrobanya adalah Air Minum dalam kemasan (AMDK).

AMDK adalah air yang telah diolah dan dikemas serta aman untuk dikonsumsi. Air minum dalam kemasan harus memenuhi persyaratan air minum dalam kemasan (AMDK) yang diatur sesuai dengan Standar Nasional Indonesia (SNI) nomor SNI-01-3553-2006. Hingga saat ini keberadaan AMDK sangat diminati oleh masyarakat karena dinilai lebih higenis dan praktis untuk memenuhi kebutuhan air minum sehari - hari. Pemanfaatan AMDK sangat dirasakan oleh masyarakat, karena AMDK merupakan solusi bagi masyarakat untuk mengkonsumsi air siap pakai.

Air kemasan yang sekarang lebih popular adalah air galon. Karena air galon lebih praktis dan bahkan lebih murah. jika dibandingkan dengan mengonsumsi air minum yang direbus dulu (Anonim, 2014). Konsumen memiliki berbagai alasan untuk membeli air minum kemasan, misalnya rasa, kenyamanan, dan gaya hidup, namun, bagi sebagian besar konsumen, keamanan dan manfaat kesehatan menjadi bahan pertimbangan yang penting (Palupi, et. al., 2011).

Tingkat ketergantungan masyarakat pada air minum dalam kemasan semakin tinggi karena minuman ini sudah menjadi kebutuhan primer bagi masyarakat. Konsumsi air minum dalam kemasan di kota Batam mencapai 186.596 rumah, paling tinggi dibandingkan dengan sumber air minum lain seperti ledeng dan sumur. Tingginya tingkat konsumsi akan air minum 
dalam kemasan disebabkan karena jenis tanah di kota Batam yang tidak dapat menyimpan air dengan baik, sehingga lebih efektif jika menggunakan waduk buatan sebagai penyimpan/penampung air, kemudian air ini di olah dan dijadikan sumber air bersih yang di alirkan ke rumah-rumah penduduk (Laporan Status Lingkungan Hidup Daerah (SLHD) daerah Prov. Kepulauan Riau Tahun 2011).

Berdasarkan paparan di atas maka perlu dilakukan identifikasi bakteri patogen Coliform pada air minum dalam kemasan. Pemeriksaan kandungan Coliform dilakukan menggunakan metode Most Probable Number (MPN) berdasarkan standar yang ditetapkan oleh kementerian kesehatan RI. Tujuan penelitian ini adalah untuk mengetahui ada atau tidaknya bakteri coliform beserta jenisnya, yang terkandung dalam air minum dalam kemasan yang diproduksi di kota Batam.

\section{METODE PENELITIAN}

Penelitian ini merupakan penelitian survei. Populasi dari penelitian ini adalah seluruh air minum dalam kemasan yang di produksi di kota batam. Pengambilan sampel dilakukan secara purposive sampling. Sampel di ambil dari 8 merek AMDK yang diproduksi di kota Batam. Penelitian ini dilakukan di laboratorium Central Teknologi Laboratorium Medik, Sekolah Tinggi Ilmu Kesehatan Perintis Padang. Penelitian dilakukan dari bulan Juni sampai Agustus, yang meliputi tahap sampling dan analisa.

Bahan yang digunakan dalam penelitian ini adalah Aquadest, Alkohol 70 \%, serta Media dan Reagensia : Lactose Broth Double Strength (LBDS), Lactose Broth Single Strength (LBSS), Brilliant Green Lactose Broth (BGLB) dan Nutrient Broth (NB). Alat yang digunakan autoclave, laminar air flow, inkubator, mikroskop, timbangan, hotplate, micropipette, lemari pendingin, jarum ose, spritus, kaca preparat, kaca penutup dan alat-alat gelas.

Terhadap sampel dilakukan identifikasi Coliform yang dilakukan dengan metoda MPN (Most Probable Number). Pengujian MPN dilakukan dengan dua tahap yaitu, Uji Praduga (Presumptive Test) menggunakan medium LB (Lactosa Broth) dan Uji Konfirmasi (Confirmative Test) menggunakan medium BGLB (Brillian green laktosa broth). Apabila uji praduga positif, maka dilakukan uji berikutnya yaitu uji konfirmasi MPN. Namun apabila uji praduga negatif, pengujian sampel selesai (Selian et al., 2014). Pada uji konfirmasi yang 
menunjukkan hasil positif, diambil 1-2 ose sampel lalu dimasukkan dalam tabung yang berisi BGLB dan diinkubasi pada suhu $37^{\circ} \mathrm{C}$. Pembacaan dilakukan setelah 24-48 jam. Hasil indek MPN dikonsultasikan dengan tabel MPN 511 menurut Formula Thomas (Jiwintarum, et. al., 2017).

\section{HASIL DAN PEMAHASAN}

Penelitian dilakukan dengan mengambil sampel Air Minum dalam Kemasan (AMDK) yang diproduksi di Kota Batam. Sampel diambil dari 8 merek yang berbeda dengan proses analisa dilakukan secara duplo dan sampling dilakukan selama 3 bulan berturut-turut atau 3 kali sampling, dari analisa bakteri coliform diperoleh index MPN (per $100 \mathrm{ml}$ ) pada Tabel 1.

Tabel 1. Hasil Nilai MPN (per 100 ml) pada Air Minum Dalam Kemasan

\begin{tabular}{|c|c|c|c|c|c|c|c|c|c|c|c|c|c|}
\hline \multirow[t]{4}{*}{ No } & \multirow{4}{*}{$\begin{array}{l}\text { Kode } \\
\text { sampel }\end{array}$} & \multicolumn{12}{|c|}{ Coliform (+) } \\
\hline & & \multicolumn{4}{|c|}{ Sampling ke-1 } & \multicolumn{4}{|c|}{ Sampling ke-2 } & \multicolumn{4}{|c|}{ Sampling ke-3 } \\
\hline & & 10 & 1 & 0,1 & MPN & 10 & 1 & 0,1 & MPN & 10 & 1 & 0,1 & MPN \\
\hline & & $\mathrm{ml}$ & $\mathrm{ml}$ & $\mathrm{ml}$ & & $\mathrm{ml}$ & $\mathrm{ml}$ & $\mathrm{ml}$ & & $\mathrm{ml}$ & $\mathrm{ml}$ & $\mathrm{ml}$ & \\
\hline 1 & AS1 & 0 & 0 & 0 & 0 & 0 & 0 & 0 & 0 & 0 & 0 & 0 & 0 \\
\hline 2 & AS2 & 0 & 0 & 0 & 0 & 0 & 0 & 0 & 0 & 0 & 0 & 0 & 0 \\
\hline 3 & AP1 & 0 & 0 & 0 & 0 & 0 & 0 & 0 & 0 & 0 & 0 & 0 & 0 \\
\hline 4 & AP2 & 0 & 0 & 0 & 0 & 0 & 0 & 0 & 0 & 3 & 0 & 0 & 9 \\
\hline 5 & AT1 & 0 & 0 & 0 & 0 & 0 & 0 & 0 & 0 & 5 & 0 & 0 & 67 \\
\hline 6 & AT2 & 0 & 0 & 0 & 0 & 5 & 1 & 1 & $\leq 979$ & 0 & 0 & 0 & 0 \\
\hline 7 & AD1 & 0 & 0 & 0 & 0 & 2 & 0 & 0 & 5 & 0 & 0 & 0 & 0 \\
\hline 8 & AD2 & 0 & 0 & 0 & 0 & 0 & 0 & 0 & 0 & 0 & 0 & 0 & 0 \\
\hline 9 & SD1 & 1 & 0 & 0 & 2 & 0 & 0 & 0 & 0 & 5 & 0 & 0 & 67 \\
\hline 10 & $\mathrm{SD} 2$ & 2 & 0 & 0 & 5 & 5 & 0 & 0 & 67 & 0 & 0 & 0 & 0 \\
\hline 11 & MI1 & 0 & 0 & 0 & 0 & 0 & 0 & 0 & 0 & 0 & 0 & 0 & 0 \\
\hline 12 & M12 & 3 & 0 & 0 & 9 & 0 & 0 & 0 & 0 & 0 & 0 & 0 & 0 \\
\hline 13 & SA1 & 0 & 0 & 0 & 0 & 0 & 0 & 0 & 0 & 0 & 0 & 0 & 0 \\
\hline 14 & SA2 & 0 & 0 & 0 & 0 & 0 & 0 & 0 & 0 & 0 & 0 & 0 & 0 \\
\hline 15 & AQ1 & 5 & 0 & 0 & 67 & 0 & 0 & 0 & 0 & 2 & 0 & 0 & 5 \\
\hline 16 & $\mathrm{AQ} 2$ & 3 & 0 & 0 & 9 & 0 & 0 & 0 & 0 & 0 & 0 & 0 & 0 \\
\hline
\end{tabular}

Tabel 2. Hasil complete test Air Minum dalam Kemasan

\begin{tabular}{|c|c|c|c|c|}
\hline \multirow[t]{2}{*}{ No } & \multirow{2}{*}{$\begin{array}{c}\text { Kode } \\
\text { sampel }\end{array}$} & \multicolumn{3}{|c|}{ Bakteri Yang dihasilkan } \\
\hline & & Sampling ke-1 & Sampling ke-2 & Sampling ke-3 \\
\hline 1 & AP2 & - & - & Klebsiella sp. \\
\hline 2 & AT1 & - & - & Klebsiella sp. \\
\hline 3 & AT2 & - & Enterobacter aerogenes & - \\
\hline 4 & AD1 & - & $\begin{array}{l}\text { Salmonela sp. dan } \\
\text { Pseudomonas sp. }\end{array}$ & - \\
\hline 5 & SD1 & Pseudomonas sp. & - & - \\
\hline 6 & SD2 & - & Pseudomonas sp. & \\
\hline 7 & MI2 & $\begin{array}{l}\text { Salmonela sp. } \\
\text { Pseudomonas } \\
\text { sp. }\end{array}$ & - & - \\
\hline 8 & $\mathrm{AQ} 2$ & Klebsiella sp. & - & - \\
\hline
\end{tabular}


Berdasarkan pengujian bakteri golongan coliform yang telah dilakukan pada uji penduga dan uji konfirmasi menunjukkan bahwa nilai MPN bakteri coliform pada air minum dalam kemasan yang di produksi di kota Batam telah melewati batas aman yang telah ditetapkan dimana hanya sampel AS dan SA yang tidak mengandung bakteri coliform, sedangkan yang lainnya mengandung bakteri coliform dengan Nilai MPN tertinggi diperoleh pada sampel AT dan terendah SD.

Berdasarkan Peraturan Menteri Kesehatan No.492/MENKES/Per/IV/2010 dan No. 907/MENKES/SK/VII/2002 batas maksimal total bakteri Coliform yang ditetapkan yaitu 0 APM/100 ml sampel. Itu artinya ada enam merek AMDK yang dianalisa tidak layak untuk dikonsumsi. Total bakteri Coliform yang diukur dilakukan dengan Most Probable Number Test (Departemen Kesehatan RI., 2011) merupakan parameter wajib penentuan kualitas air minum secara mikrobiologi. Jika di dalam $100 \mathrm{ml}$ sampel airdidapatkan sel bakteri Coliform maka dimungkinkan terjadi diare dan gangguan pencernaan lain (Suriawiria, 2008).

Pada tes pendugaan didapatkan delapan dari enam belas sampel atau 50\% sampel tidak memenuhi persyaratan secara mikrobiologi yang telah ditetapkan oleh Peraturan Menteri Kesehatan No. 492 Tahun 2010 (Departemen Kesehatan RI., 2011). Dari delapan sampel penelitian yang positif, semuanya memenuhi syarat untuk dilakukan uji secara kualitatif. Setelah dilakukan uji selanjutnya, kedelapan sampel menunjukkan hasil positif pada tes pelengkap dan menunjukkan pertumbuhan bakteri Klebsiella sp., Enterobacter aerogenes, Pseudomonas sp., dan Salmonella sp.

Pada Tabel 2 dapat diketahui bahwa Bakteri Klebsiella sp., ditemukan pada sampel AP dan AT pada sampling ketiga serta sampel AQ pada sampling pertama. Bakteri Enterobacter aerogenes hanya di temukan pada sampel AT, untuk bakteri Pseudomonas sp., ditemukan pada 3 merek yaitu merek AD, SD dan MI sedangkan Salmonella sp. diperoleh pada merek AD dan MI. Pada Nilai MPN yang tertinggi ternyata didapatkan sampel mengandung bakteri Enterobacter aerogenes.

Nilai MPN yang melebihi ambang batas dan adanya bakteri yang ditemukan, bisa terjadi karena berbagai faktor, mulai dari bahan baku, proses produksi, distribusi maupun sampai dikonsumen itu sendiri. Hasil penelitian Kasim, et. al., (2014) juga menyatakan bahwa untuk mendapatkan kualitas air minum yang bagus diperlukan air baku yang kondisi air bakunya memenuhi persyaratan, sehingga tidak membutuhkan 
peralatan ataupun prosedur pengolahan yang lebih layak untuk memperoleh air yang siap untuk dikonsumsi. Air baku ini bisa bersumber dari air angkasa, air permukaan, maupun air tanah. Jumlah dan jenis bakteri berbeda-beda sesuai dengan tempat dan kondisi yang mempengaruhinya. Saat ini mutu lingkungan air menurun yang berdampak pada kualitas ketersediaan air sebagai bahan baku air minum. Hal ini disebabkan karena meningkatnya pencemaran lingkungan.

Pada proses pengolahan air baku menjadi air minum juga biasa menyebabkan terkontaminasi bakteri, ini dapat terjadi apabila proses pengolahannya kurang sempurna. Metode sterilisasi yang sering digunakan adalah penyinaran dengan ultraviolet, ozonisasi, gabungan penyinaran dan ozonisasi, serta reserved osmosis. Sterilisasi dengan penyinaran ultraviolet tidak efektif untuk membunuh mikroorganisme yang mengkontaminasi apabila tidak memenuhi persyaratan seperti intensitas cahaya yang tidak tepat, kecepatan air yang tidak sesuai, serta lampu UV yang digunakan terus menerus tanpa diganti (Sembiring, 2008). Sedangkan pada metode sterilisasi dengan ozonisasi, efektivitasnya tergantung pada temperatur yang digunakan (Said, 2011).

Afif et. al., (2015) dan Athena, et. al., (2004) menyatakan bahwa beberapa faktor yang dapat mempengaruhi kualitas produk air minum yang dihasilkan adalah air baku, kebersihan operator, penanganan terhadap wadah (packaging) pemeliharaan peralatan serta penanganan pengolahan dan pendistribusian air. Kondisi dari filter yang digunakan dan lamanya penyimpanan air juga akan berakibat pada pertumbuhan bakteri dalam air.

Faktor yang dapat mempengaruhi kualitas bakteriologis dari suatu air minum kemasan adalah saat proses pengangkutan air dari tempat produksi ke konsumen atau distributor. Dimana pada saat pengangkutan kadang yang tidak tertutup sehingga terpapar oleh sinar matahari. Yang mengakibatkan berkembangnya bakteri dalam kemasan. Selanjutnya proses penyimpanan yang tidak layak juga akan menimbulkan berkembangnya bakteri dalam air, dimana air merupakan tempat yang paling mudah berkembangnya bakteri (Gafur, et.al., 2017; Hussain et al., 2011).

Keberadaan bakteri koli dalam air minum tidak diharapkan karena bakteri koli merupakan parameter ada tidaknya materi kotoran/fekal yang bersinggungan materi air (Harsojo \& Irawati 2011). Oleh karena itu mendeteksi bakteri koli sangat penting karena akan diketahui apakah bahan yang diteliti tersebut masih laik dikonsumsi atau 
tidak. Adanya bakteri koli dalam materi dimungkinkan akan terdapat bakteri patogen lainnya yang dapat membahayakan untuk konsumen (Harsojo \& Kadir, 2013; Suriawiria, 2008). Menurut Sengupta \& Saha (2013) manusia yang terpapar oleh air yang terkontaminasi Coliform mengakibatkan gejala demam, diare dan kram abdominal, nyeri dada, atau menyebabkan penyakit hepatitis. Selain E. coli, patogen fekal lain yang menjadi ancaman bagi kesehatan adalah Salmonella, Shigella, dan Psuedomonas aeruginosa.

\section{KESIMPULAN}

Pada perhitungan Most Probable Number (MPN) terdapat 2 merek AMDK yang tidak mengandung Bakteri coliform. Nilai MPN berkisar antara $2-\geq 979$ MPN/100 ml. Dari 16 sampel yang dianalisa diperoleh 8 sampel mengandung bakteri Klebsiella sp., Enterobacter aerogenes, Pseudomonas sp., dan Salmonella sp dan dari 8 merek yang dianalisa 6 merek tidak layak dikonsumsi.

\section{REFERENSI}

Afif, F., Erly, \& Endrinaldi, 2015. Identifikasi Bakteri Escherichia Coli pada Air Minum Isi Ulang yang Diproduksi Depot Air Minum Isi Ulang di Kecamatan Padang Selatan, Jurnal kesehatan Andalas, 4(2):376-380.

Anonim, 2014. Air Minum dalam Kemasan, Standar Nasional Indonesia, SNI 01-3553-2006.

Athena, A., D, Anwar M., Hendro, M., \& Muhasim, 2004. Kandungan Pb, Cd, Hg dalam Air Minum dari Depot Air Minum Isi Ulang di Jakarta, Tangerang dan Bekasi. Jurnal Ekologi Kesehatan, 3(3): 148-152.

Departemen Kesehatan RI. (2011). Profil Kesehatan Indonesia 2010. Jakarta.

Gafur, A., Kartini, A. D., \& Rahman, 2017. Studi Kualitas Fisik Kimia dan Biologis pada Air Minum Dalam Kemasan Berbagai Merek yang Beredar di Kota Makassar Tahun 2106. Higiene, 3(1). 37-46.

Harsojo, \& Irawati Z., 2011. Kontaminasi Awal dan Dekontaminasi Bakteri Patogen pada Jeroan Sapi dengan Iradiasi Gamma. J. Iptek Nuklir Ganendra, 14(2): 95-101.

Harsojo, \& Kadir I. (2013). Study of Drinking Water Fungi And Its Pathogenic Effect s On Human Beings From District Bhimber, Azad Kashmir, Pakistan. J. Iptek Nuklir Ganendra, 16(1): 9-17.

Hussain, T., Ishtiaq, M., Hussain, A., \& Sultana, K. (2011). Study of Drinking Water Fungi And Its Pathogenic Effects On Human Beings From District Bhimber, Azad Kashmir, Pakistan. Pak. J. Bot, 43(5): 2581-2585. 
Jiwintarum, Y., Agrijanti, \& Septiana, B. L. (2017). Most Probable Number (MPN) Coliform Dengan Variasi Volume Media Lactose Broth Single Strength (LBSS) Dan Lactose Broth Double Strength (LBDS). Jurnal Kesehatan Prima, 11(1):11-17.

Kasim, K. P., Setiani, O., \& Endah W, N. (2014). Faktor-Faktor yang Berhubungan dengan Cemaran Mikroba dalam Air Minum Isi Ulang pada Depot Air Minum Kota Makassar. Jurnal Kesehatan Lingkungan Indonesia, 13(2):39-44.

Kusuma, E. A., \& Rasyid, R. (2015). Artikel Penelitian Identifikasi Bakteri Coliform pada Air Kobokan di Rumah Makan Kelurahan Andalas Kecamatan Padang Timur. Jurnal Kesehatan Andalas, 4(3):845-849.

Palupi, W., Belawati, S. F., \& Monica, E., 2011. Pedoman Mutu Air Minum. EGC. Jakarta

Sembiring, F. Y., 2008. Manajemen Pengawasan Sanitasi Lingkungan Dan Kualitas Bakteriologis Pada Depot Air Minum Isi Ulang kota Batam. Tesis. Universitas Sumatera Utara. Medan.

Sengupta, C., \& Saha, R., 2013. Understanding coliforms - a short review 1 Introduction 2 Definition of coliforms 3 Environmental significance. International Journal of Advanced Research, 1(4):16-25.

Soemirat, S. J., 2009. Kesehatan Lingkungan. Gadjah Mada University Press. Yogyakarta.

Suriawiria, U., 2008. Mikrobiologi Air dan Dasar-dasar Pengolahan Buangan Secara Biologis. Alumni. Bandung.

Winata, E., \& Hartantyo, E., 2013. Kualitas Air Tanah di Sepanjang Kali Gajah Wong Ditinjau Dari Pola Sebaran Escherichia Coli (Studi Kasus Kecamatan Umbulharjo), Jurnal Fisika Indonesia, 17 (50): 8-11. https://doi.org/10.22146/jfi.24415 